\title{
RELATIONSHIP OF BLACK LAYER AND MILK LINE DEVELOPMENT ON MAIZE SEED MATURITY ${ }^{1}$
}

\author{
R.D. VIEIRA'; L. MINOHARA²; N.M. de CARVALHO²; M.C.M. BERGAMASCHI² \\ ${ }^{2}$ Faculdade de Ciências Agrárias e Veterinárias/UNESP, CEP: 14870-000 - Jaboticabal, SP, Brasil
}

\begin{abstract}
ARSTRACT: The relationship of black layer and milk line development on maize seed maturity was evaluated under tropical conditions. Seed moisture (g.kg-1), standard germination - SG (7 days, $\left.25^{\circ} \mathrm{C}\right)$, and vigor, using accelerated aging-AA (96 hours, $42^{\circ} \mathrm{C}$ and $100 \%$ of $\mathrm{RH}$ ), cold test-CT only in $1991 / 92$ (7 days at $10^{\circ} \mathrm{C}$ and 7 days at $25^{\circ} \mathrm{C}$ ) and electrical conductivity-EC (four 50-seed samples, 24 hours imbibition at $25^{\circ} \mathrm{C}$ ) and mill line and black layer formation (using a five-stage rating system) were determined at 3 to 4 days intervals, using two genotypes (hybrid CX 133 and variety IAC 100) during the crop seasons of 1990/91 and 1991/92. The results showed that physiological maturity was reached before stage 4 , based on seed germination and vigor (AA and CT) values, which occurred before that stage and presented the lowest values of EC. On the other hand, moisture content levels of 300 to 350 g.kg-1 were reached only at stage 4 . The milk line ratings proved useful in predicting physiological maturity as well as the harvest maturity.
\end{abstract}

Key Words: germination, vigor, accelerated aging, cold test, electrical conductivity

\section{RELAÇĀO ENTRE O DESENVOLVIMENTO DA CAMADA NEGRA E DA LINHA DE TRANSFORMAÇĀO EM AMIDO E A MATURIDADE DE SEMENTES DE MILHO}

RESUMO: A relação entre o desenvolvimento da camada negra e da linha de transformaçāo em amido e a maturidade fisiologica de sementes de milho foi estudada durante dois anos agricolas (1990/91 e 1991/92). Para atingir os objetivos do trabalho, avaliou-se o grau de umidade, a germinaçāo, o vigor (envelhecimento acelerado, teste frio e condutividade elétrica) e o desenvolvimento da camada negra e da linha de transformação em amido para dois genotipos (CX 133 e IAC 100). Com base nos resultados de germinação e vigor das sementes verificou-se que a maturidade fisiologica foi alcançada antes do estadio 4. Por outro lado, graus de umidade de 30 a $35 \%$ foram alcançados somente no estádio de desenvolvimento 4. A linha de transformação em amido provou ser um instrumento útil para predizer a maturidade fisiológica e de colheita para sementes de millho.

Descritores: germinação, vigor, envelhecimento acelerado, condutividade elétrica, teste frio

\section{INTRODUCTION}

Some authors (RENCH \& SHAW, 1971) determined physiological maturity (PM) of maize seed using moisture concentration and dry matter content. Moisture and maximum dry weight parameters vary in function of genotype and planting date (KNITTLE \& BURRIS, 1976). According to ALDRICH (1943) the maximum potential for physiological quality of maize seed occurred when the seeds showed $65 \%$ of dry matter accumulation and $35 \%$ of moisture content.

Seed development of maize is accompanied by changes in the moisture content, which reduces significantly by the end of the whole process (HUNTER et al., 1991), by the development of the black layer (BL) in the placental-chalazal region of the seed (DAYNARD \& DUNCAN, 1969; RENCH \& SHAW, 1971; DAYNARD, 1972; HUNTER, 1989; TEKRONY et al., 1994) and by the progressive development of the milk line as a result of milky endosperm solidification, beginning at seed apex and ending at the base (AFUAKWA \& CROOKSTON, 1984; HUNTER et al., 1991).

These morphological and physiological changes occurring during seed development have been used to determine physiological maturity of maize seed. Using a

\footnotetext{
${ }^{1}$ Paper presented at the ASA/CSSA/SSSA Annual Meeting, Cincinnati, November 7-12, 1993.
} 
rating system (stages 1 to 5), based on black layer and milk line development, many researchers have identified the point of physiological maturity and optimun harvest time ( DAYNARD \& DUNCAN, 1969; RENCH \& SHAW, 1971; AFUAKWA \& CROOKSTON, 1984; HUNTER et al., 1991; TEKRONY et al., 1994).

According to HUNTER et al. (1991), the black layer and milk line at stage 4 represent useful and reliable indicators of maize seed physiological maturity, mainly because before that stage seeds will have already reached maximum dry matter weight. On the other hand, CARTER \& PONELEIT (1973) observed that the black layer at stage 5 was a better indicator of maize seed physiological maturity, since the beginning of the development of this layer can be observed around one month after pollination (HUNTER et al., 1991).

Nevertheless, environmental factors influence the development and maturation of maize seed and adverse conditions, such as water deficit that can cause leaf area reductions and faster development of the black layer (AFUAKWA \& CROOKSTON, 1984). The present study was undertaken to evaluate black layer and milk line development under tropical conditions where temperature stress is likely to occur.

\section{MATERIALS AND METHODS}

During two agricultural years (1990/ 91 and 1991/92), two maize genotypes (hybrid CX 133 and variety IAC 100) were grown in $100 \mathrm{~cm}$ rows apart in a Hapludox Soil at the Experimental Farm of FCAV/UNESP, Campus of Jaboticabal, Brazil. The maize crop was fertilized and managed according to technical recommendations of FORNASIERI FILHO (1992).

In both years, from plants with uniform appearance, ears with 0.5 to $2.5 \mathrm{~cm}$ of visible silk were tagged for harvesting (HUNTER et al., 1991). Seed moisture content was determined at every 3 to 4 days during a period of 22 to 62 days after flowering (DAF). At the indicated intervals, 5 ears were harvested at random and from the middle position of each one of them 20 seeds were removed for moisture determination. Ten additional seeds from the same ears and position were examined for black layer (BL) and milk line (ML) development. The milk line stages considered were those described by HUNTER et al. (1991).
The 10 seeds used in milk line evaluations were cut in half vertically through the germinal-abgerminal plane and classified by stage of BL development. The BL rating system described by RENCH \& SHAW (1971) and modified by HUNTER et al. (1991) was used.

The physiological seed quality was determined by standard germination (BRASIL, 1980 ) and vigor tests. Accelerated aging, cold test and electrical conductivity (ASSOCIATION OF OFFICIAL SEED ANALYSTS, 1983) were the vigor tests employed.

The experimental design was a completely randomized block, each genotype consisting of a separate experiment. Statistical comparisons of means were performed using the least significant difference test (LSD).

\section{RESULTS}

During the agricultural year of 1990/91 (TABLES 1 and 3), the moisture content decreased from $483 \mathrm{~g} \cdot \mathrm{kg}^{-1}$ at 22 DAF to $264 \mathrm{~g} \cdot \mathrm{kg}^{-1}$ at $47 \mathrm{DAF}$ for the cv. IAC 100 and from 459 to $301 \mathrm{~g} . \mathrm{kg}^{-1}$ at 22 to 54 DAF for the genotype CX 133, respectively. As shown on TABLE 3 , at 47 DAF seed moisture content reached a value in accordance to air relative humidity.

Following the decrease in moisture content, the milk line (ML) and black layer (BL) development were initiated. The beginning of milk line and black layer development was already noticeable at 22 DAF (TABLES 1 and 3). Stage 5 was reached around 43 DAF for IAC 100 and 54 DAF for CX 133 genotypes. Stage 4 was reached at 36-39 DAF for IAC 100 and 43 for CX 133.

Maximum seed quality values in terms of standard germination were found as early as 25-26 DAF. Germination values at 25 and 29 DAF for IAC 100 and CX 133, respectively, did not differ from the last harvest for both genotypes (TABLES 1 and 3).

Seed vigor evaluated by accelerated aging showed values statistically similar between 29 and 47 DAF (IAC 100) (TABLE 1). The electrical conductivity showed high values (24.3 and 26.1 $\mu$ mhos. $\left.\mathrm{cm}^{-1} \cdot \mathrm{g}^{-1}\right)$ at the beginning of the 1991 harvest (22DAF) for both genotypes (TABLES 1 and 3) and decreased until it reached around 5 $\mu$ mhos.cm ${ }^{-1} \cdot \mathrm{g}^{-1}$ at 43 DAF for IAC 100 (TABLE 1) and at 50 DAF for CX 133 (TABLE 3). 
TABLE 1 - Moisture content (MC) at harvest time, milk line (ML) and black layer (BL) development, standard germination (SG) and vigor (accelerated aging - AA and electrical conductivity - EC) of maize seed, cv. IAC 100. 1990/91.

\begin{tabular}{|c|c|c|c|c|c|c|c|c|}
\hline \multicolumn{2}{|c|}{$\begin{array}{c}\text { Harvest } \\
\text { (DAF) }^{1}\end{array}$} & $\begin{array}{c}\mathrm{MC} \\
\%\end{array}$ & \multicolumn{2}{|c|}{$\mathrm{ML}^{2}$} & $\mathbf{B L}^{2}$ & SG & $\begin{array}{l}\text { AA } \\
-\end{array}$ & $\begin{array}{c}\text { EC } \\
\mu \mathrm{mhos} /\end{array}$ \\
\hline 22 & 48.3 & & 1.50 & 2.05 & 94 & 65 & & 24.3 \\
\hline 25 & 46.9 & & 2.30 & 2.45 & 98 & 69 & & 19.3 \\
\hline 29 & 41.5 & & 2.35 & 3.40 & 99 & 78 & & 16.6 \\
\hline 32 & 40.0 & & 2.85 & 3.65 & 100 & 84 & & 11.6 \\
\hline 36 & 30.7 & & 3.90 & 4.15 & 98 & 85 & & 8.4 \\
\hline 39 & 33.3 & & 4.70 & 4.75 & 98 & 85 & & 8.2 \\
\hline 43 & 30.1 & & 5.00 & 5.00 & 99 & 82 & & 5.8 \\
\hline 47 & 26. & & 5.00 & 5.00 & 96 & 82 & & 5.4 \\
\hline $\mathrm{CV}$ & $\%)$ & 2.14 & $\begin{array}{l}4.29 \\
4\end{array}$ & 4.60 & 0.61 & 7.31 & 10.3 & \\
\hline LSE & $(5 \%)$ & 3.3 & 0.46 & 0.72 & 2.5 & 16.6 & 5.3 & \\
\hline
\end{tabular}

' DAF = Days after flowering

${ }^{2}$ Rate system varying from 1 to 5

In the agricultural year of 1991/92 (TABLES 2 and 4), the harvest period was longer, and the cold test was added to the vigor tests to evaluate seed vigor. Moisture content decreased from 529 to $218 \mathrm{~g} \cdot \mathrm{kg}^{-1}$ (average of the two genotypes) from 24 to 62 DAF. Starting at 52 DAF, seed moisture content started to show a great influence of the environmental conditions, mainly of the air relative humidity.

Similarly to what was observed in the previous season, as moisture content decreased, BL and ML developments could be noticed. Milk line development became visible at 27 and black layer at 31 DAF. Stage 4 was reached approximately at 45 DAF and stage 5 around 52 DAF, for both genotypes.

Germination values at 27 DAF for IAC 100 and at 31 for CX 133, were already statistically similar to those obtained up to 62 DAF. Seed vigor, on the other hand, showed peak results at 31 DAF for both genotypes. As seed developed electrical conductivity decreased from initial values of 38.4 (IAC 100) and 30.7 (CX 133) to approximately $4 \mu \mathrm{mhos} . \mathrm{cm}^{-1} \cdot \mathrm{g}^{-1}$, at $50 \mathrm{DAF}$ for both genotypes. After 41 DAF for IAC 100 and 48
DAF for CX 133, electrical conductivity results were statistically similar, showing values close to $4 \mu$ mhos. $\mathrm{cm}^{-1} \cdot \mathrm{g}^{-1}$ (TABLES 2 and 4 ).

TABLE 2 - Moisture content (MC) at harvest time, milk line (ML) and black layer (BL) development, standard germination (SG) and vigor (accelerated aging - AA, cold test $\mathrm{CT}$ and electrical conductivity - EC) of maize seed, cv. IAC 100 1991/92.

\begin{tabular}{lcccccccc}
\hline & & & & SG & AA & CT \\
Harvest & MC & ML $^{2}$ & BL $^{2}$ & $\cdots$ & & & \\
(DAF) & $\%$ & & & & $\%$ & & $\begin{array}{c}\text { Mmhos/ } \\
\text { cm.g }\end{array}$ \\
& & & & & & & \\
\hline 24 & 53.4 & 1.00 & 1.00 & 74 & 61 & 69 & 38.4 \\
27 & 48.4 & 1.63 & 1.00 & 90 & 64 & 77 & 31.6 \\
31 & 42.5 & 1.73 & 2.03 & 90 & 77 & 92 & 20.3 \\
34 & 41.7 & 2.40 & 2.43 & 93 & 87 & 96 & 16.7 \\
38 & 38.9 & 2.57 & 2.50 & 97 & 86 & 98 & 13.3 \\
41 & 36.0 & 3.57 & 3.40 & 95 & 86 & 97 & 12.4 \\
45 & 33.1 & 4.23 & 4.13 & 98 & 89 & 97 & 6.4 \\
48 & 28.1 & 4.80 & 4.77 & 98 & 91 & 96 & 5.1 \\
52 & 27.2 & 4.97 & 4.97 & 97 & 86 & 96 & 4.4 \\
55 & 26.7 & 5.00 & 5.00 & 94 & 81 & 96 & 4.3 \\
59 & 23.3 & 5.00 & 5.00 & 96 & 87 & 95 & 4.3 \\
62 & 22.0 & 5.00 & 5.00 & 95 & 87 & 97 & 4.4 \\
\hline CV (\%) & 2.80 & 5.66 & 6.36 & 3.23 & 6.95 & 1.76 & 14.74 \\
LSD (5\%) & 2.9 & 0.59 & 0.65 & 8.9 & 17.0 & 4.8 & 5.9 \\
\hline
\end{tabular}

1 DAF = Days after flowering

${ }^{2}$ Rate system varying from 1 to 5

Independent of the genotypes and years low coefficients of variation were obtained.

\section{DISCUSSION}

The hybrid maize seed industry is increasingly conscious of the necessity of increasing the quantity and quality of seed it produces. Physiological maturity (PM) and the harvest time of maize seed have been determined based on seed dry matter weight and moisture content (MC).

Both yield and seed quality are likely to be improved when the harvest is made at physiological maturity. In practice, however working with these characteristics poses some 
serious difficulties, primarily because they depend on laboratory determinations and they tend to be influenced by environmental as well as by genetic factors (RENCH \& SHAW, 1971; CARTER \& PONELEIT, 1973; DAYNARD, 1972, among others).

This work is an attempt to relate milk line (ML) and the black layer (BL) development, the reduction of moisture content of maize seed and their association with germination and vigor of the seeds. All tests were related to $P M$ and the possibility of identifying harvest time using the black layer and milk line formation.

Seed moisture content and ML and BL ratings showed similar trends during seed development and maturation across agricultural years and genotypes (TABLES 1-4). During 1990/91, BL development of the genotypes CX 133 reached stage 3 earlier than IAC 100 (TABLES 1 and 3). However, in 1991/92, both ML and BL reached this stage at approximately the same time, close to 40 DAF (TABLES 2 and 4). Stage 4 was reached at 36 and 43 DAF for IAC 100 and CX 133, respectively, during $1990 / 91$ and at $45 \mathrm{DAF}$ for both genotypes during 1991/92.

When the seeds reached stage 4 (ML and $B L$ ), seed moisture content ranged from 324 to
400 g. $\mathrm{kg}^{-1}$ across genotypes and years (TABLES 14); showing that both ML and BL are reliable indicators of seed maturity.

Seed physiological quality was generally high from 30 DAF onwards. Germination was relatively high even at ML and BL stages 2 to 3 when seed moisture content was above $400 \mathrm{~g} . \mathrm{kg}^{-}$ 1. A similar trend was observed for vigor evaluated by AA and CT (1991/92). Electrical conductivity (EC) values decreased with seed development being the values lower than $10 \mu$ mhos $\mathrm{cm}^{-1} \mathrm{~g}^{-1}$ at stage 4 (ML and BL) across years and genotypes. This pattern of variation in EC values as seeds mature was also reported by POWELL (1986). The reduction in EC has been associated with the development of cellular membranes and their completion and structural organization accompanying physiological maturity.

The results of this study showed that seed moisture content at BL stage 4 varied from 307 to $343 \mathrm{~g} . \mathrm{kg}^{-1}$ across genotypes and years.

HUNTER et al. (1991) encountered for the same stage 293 to $415 \mathrm{~g} \cdot \mathrm{kg}^{-1}$, also across genotypes and agricultural years. It was also observed that both BL and ML characteristics reached stage 5 after the seeds had reached physiological maturity.

TABLE 3. Moisture content (MC) at harvest time, milk line (ML) and black layer (BL) development, standard germination (SG) and vigor (accelerated aging - AA and electrical conductivity - EC) of maize seed, hybrid CX 133. 1990/91.

\begin{tabular}{cllllllc}
\hline \hline & & & & SG & AA & \\
\cline { 6 - 7 } $\begin{array}{c}\text { Harvest } \\
\text { (DAF) }\end{array}$ & $\begin{array}{l}\text { MC } \\
\%\end{array}$ & ML $^{2}$ & BL $^{2}$ & & $\%$ & $\begin{array}{c}\text { EC } \\
\mu \text { mhos/cm.g }\end{array}$ \\
\hline 22 & 45.9 & 1.50 & 2.95 & 92 & 81 & 26.1 \\
26 & 46.4 & 2.30 & 3.30 & 90 & 88 & 19.5 \\
29 & 41.7 & 2.55 & 3.55 & 98 & 87 & 13.0 \\
33 & 40.6 & 3.00 & 3.60 & 95 & 90 & 12.5 \\
36 & 39.6 & 3.40 & 3.65 & 95 & 91 & 9.8 \\
40 & 34.9 & 3.75 & 3.75 & 92 & 91 & 8.4 \\
43 & 34.3 & 4.25 & 4.10 & 93 & 88 & 9.5 \\
47 & 26.5 & 4.60 & 4.55 & 95 & 91 & 6.7 \\
50 & 29.7 & 4.85 & 4.85 & 99 & 93 & 4.5 \\
54 & 30.1 & 5.00 & 5.00 & 96 & 92 & 5.3 \\
\hline CV (\%) & 3.80 & 5.68 & 3.72 & 2.00 & 2.74 & 8.86 \\
LSD (5\%) & 5.7 & 0.81 & 0.59 & 7.6 & 7.2 & 4.1 \\
\hline \hline
\end{tabular}

1 DAF = Days after flowering

${ }^{2}$ Rate system varying from 1 to 5 
TABLE 4. Moisture content (MC) at harvest time, milk line $(M L)$ and black layer (BL) development, standard germination (SG) and vigor (accelerated aging - AA, cold test - CT and electrical conductivity - EC) of maize seed, hybrid CX 133 - 1991/92.

\begin{tabular}{cccccccc}
\hline \hline $\begin{array}{l}\text { Harvest } \\
\text { (DAF) }\end{array}$ & $\begin{array}{c}\text { MC } \\
\%\end{array}$ & ML $^{2}$ & BL $^{2}$ & SG & AA & CT & EC \\
\hline 24 & 52.4 & 1.00 & 1.00 & 89 & 78 & 78 & 30.7 \\
27 & 48.0 & 1.57 & 1.00 & 87 & 75 & 84 & 27.2 \\
31 & 43.0 & 2.00 & 1.87 & 92 & 89 & 93 & 18.5 \\
34 & 42.2 & 2.27 & 2.23 & 92 & 90 & 97 & 12.8 \\
38 & 39.3 & 2.50 & 2.60 & 94 & 83 & 96 & 10.7 \\
41 & 35.4 & 3.53 & 3.47 & 94 & 83 & 98 & 9.5 \\
45 & 32.4 & 4.23 & 4.03 & 95 & 92 & 99 & 4.6 \\
48 & 29.8 & 4.53 & 4.40 & 95 & 88 & 97 & 4.7 \\
52 & 26.4 & 4.70 & 4.73 & 96 & 85 & 97 & 5.4 \\
55 & 27.1 & 5.00 & 5.00 & 95 & 88 & 97 & 4.4 \\
59 & 24.4 & 5.00 & 5.00 & 94 & 90 & 97 & 3.9 \\
62 & 21.6 & 5.00 & 5.00 & 94 & 92 & 95 & 4.1 \\
\hline CV (\%) & 2.42 & 5.91 & 5.29 & 1.34 & 4.27 & 2.03 & 10.17 \\
LSD (5\%) & 2.5 & 0.61 & 0.53 & 3.7 & 10.9 & 5.7 & 3.4 \\
\hline \hline
\end{tabular}

DAF $=$ Days after flowering

${ }^{2}$ Rate system varying from 1 to 5

It was shown that ML and BL can be used to identify PM and thereby harvest time which will allow production and high quality maize seed.

It was found that physiological maturity point associated with stage 5 of BL and ML (ALDRICH, 1943; AFUAKWA \& CROOKSTON, 1984; DAYNARD \& DUNCAN, 1969; RENCH \& SHAW, 1971; CARTER \& PONELEIT, 1973), occurred earlier as verified by HUNTER et al. (1991) and TEKRONY et al. (1994). These authors concluded that harvesting can be made at stage 4 (ML and BL), without loss of physiological seed quality. Our results support the conclusion that harvesting can be made between stages 3 and 4 . In the field the ML was a better indicator being more useful and reliable in identifying the different stages.

\section{ACKNOWLEDGEMENTS}

This work was partially supported by FAPESP through a scholarship of L. Minohara. We also thank Zeneca Seeds, Cravinhos, SP and the Agronomic Institute of Campinas-IAC, Campinas - SP.

Sci. agric., Piracicaba, 52(1):142-147, jan./abr. 1995

\section{REFERENCES}

AFUAKWA, J.J.; CROOKSTON, R.K. Using the kernel milk line to visually monitor grain maturity in maize. Crop Science, Madison, v.24, n.4, p.687-691, 1984.

ALDRICH, S.R. Maturity measurements in corn and an indication that grain development continues after prematures cutting. Journal of the American Society Agronomy, Madison, v.35, n.7, p.667-680, 1943.

ASSOCIATION OF OFFICIAL SEED ANALYSTS. Seed vigor testing handbook. Springfield: AOSA, 1983. 93p. (Contribution, 32)

BRASIL. Ministério da Agricultura. Regras para análise de sementes. Brasília: Departamento Nacional de Produção Vegetal, 1980. 188p.

CARTER, M.W.; PONELEIT, C.G. Black layer maturity and filling period variation among inbred lines of corn (Zea mays L.). Crop Science, Madison, v.13, n.4, p.436-439, 1973.

DAYNARD, T.B. Relationships among black layer formation, grain moisture percentage, and heat unit accumulation in corn. Agronomy Journal, Madison, v.64, n.6, p.716-719, 1972. 
DAYNARD, T.B.; DUNCAN, W.G. The black layer and grain maturity in corn. Crop Science. Madison, v.9, n.4, p.473-476, 1969.

FORNASIERI FILHO, D. A cultura do milho. Jaboticabal: FUNEP, 1992, 273p.

HUNTER, J.L. Relationship between the stage for corn seed maturation and assimilate supply, assimilate uptake and seed quality. Lexington, 1989, 140p. Thesis (PhD) - University of Kentucky.

HUNTER, J.L., TEKRONY, D.M., MILES, D.F., EGLI, D.B. Corn seed maturity indicators and their relationship to uptake of Carbon-14 assimilate. Crop Science, Madison, v.31, n.5, p.1309-1313, 1991.

KNITTLE, K.H.; BURRIS, J.S. Effect of kernel maturation on subsequent seedling vigor in maize. Crop Science, Madison, v.16, n.6, p.851-855, 1976.
POWELL, A.A. Cell membranes and seed leachate conductivity in relation to the quality of seed for sowing. Journal of Seed Technology, East Lansing, v.10, n.2, p.81-100, 1986.

RENCH, W.E.; SHAW, R.H. Black layer development in corn. Agronomy Journal, Madison, v.63, n.2, p.303-305, 1971 .

TEKRONY, D.M.; HUNTER, J.L.: VIEIRA, R.D. Relationship of black layer maturity to seed vigor across several maize genotypes. In: ASA/CSSA/SSSA ANNUAL.MEETINGS, 86., 1994. Seattle. Agronomy abstracts... Madison: American Society of Agronomy, 1994. p.177.

Entregue para publicação em 06.07.94 Aceito para publicação em 17.08.94 